\title{
Pathways to New $\beta$ Cells
}

\author{
Q. Zhou AND D.A. Melton \\ Department of Stem Cell and Regenerative Biology, Howard Hughes Medical Institute, \\ Harvard Stem Cell Institute, Harvard University, Cambridge, Masssachusetts 02138
}

\begin{abstract}
Diabetes is a leading health problem of the world and its prevalence continues to rise. With Type I diabetes, and in some patients with Type II, the lack of insulin can be counterbalanced by providing new $\beta$ (insulin-producing) cells. For Type I diabetes, treating the autoimmune attack remains a serious challenge. Several strategies to produce new $\beta$ cells have been proposed. These include differentiation from embryonic stem cells, proliferation of existing adult $\beta$ cells, derivation from putative adult progenitors/stem cells, and reprogramming of non- $\beta$ cells to $\beta$ cells. Each of these strategies has distinct merits and risks, and they are at different stages of understanding and development. In particular, the approach based on differentiation from embryonic stem cells has had strong support and in recent years has made notable progress. Nevertheless, significant hurdles remain to transform the current research into future therapies. To expedite this transformation, we believe particular emphasis should be placed on overcoming key knowledge gaps in $\beta$-cell biology, developing strategies that produce patient-specific $\beta$ cells, and carefully addressing potential treatment-related complications or limitations.
\end{abstract}

Many aspects of human physiology are regulated by insulin, a hormone produced exclusively by $\beta$ cells of the pancreas. Insulin insufficiency is the cause of type I diabetes, where $\beta$ cells are selectively destroyed by autoimmune attack, and type II diabetes, where normal insulin supplies fail to meet demand due to impaired insulin sensitivity in peripheral organs and $\beta$-cell failure (Bell and Polonsky 2001). Although both types of diabetes can be treated effectively by insulin injections, the long-term health of diabetic patients appears to critically depend on how insulin is delivered (Kahn 2004; Daneman 2006). Continuous release in a measured fashion relative to physiological glucose levels is clearly beneficial. So far, attempts to mechanically mimic the action of $\beta$ cells have fallen short; evolution has produced a cell with exquisite sensitivity, response time, and capacity to measure glucose and release insulin in a physiological manner (Kahn 2004). The best way to supply insulin is clearly to use $\beta$ cells.

Type I diabetes patients could to benefit from a supply of new $\beta$ cells. Although the cause of type I diabetes is autoimmune attack on $\beta$ cell and a cure requires understanding and stopping autoimmunity, transplanted cadaveric islets have demonstrated impressive relief from diabetic symptoms (Lakey et al. 2006). The demand for transplantable new $\beta$ cells, however, far outstrips available supplies. In addition, it would be ideal to supply autologous $\beta$ cells to eliminate the need for immunosuppression (in the case of Type II diabetes; for Type I, blocking the autoimmune attack remains a key hurdle). Over the years, several strategies to produce new $\beta$ cells have been proposed. These include directed differentiation from embryonic stem (ES) cells, proliferation of existing $\beta$ cells, derivation from putative adult endocrine progenitor cells, and more recently, reprogramming of non- $\beta$ cells to $\beta$ cells. Each of these strategies exploits a different aspect of $\beta$-cell biology. Although notable progress has been made, significant challenges remain and discoveries will be needed in order to translate this research into therapy. Here, we briefly review key areas of $\beta$-cell development and critically evaluate the current approaches to produce new $\beta$ cells.

\section{EMBRYONIC DEVELOPMENT OF $\beta$ CELLS}

\section{Pancreatic Morphogenesis}

$\beta$ cells first arise in the pancreas during embryogenesis (Slack 1995; Edlund 2001). During early embryogenesis, it is thought that multiple signals, including some from blood vessels, induce part of the early endoderm to form the future pancreas (Lammert et al. 2001; Zaret 2008). From this domain, two pancreatic buds arise. The epithelium of the buds later sprouts finger-like protrusions into the surrounding mesenchyme to initiate branching morphogenesis. Several rounds of branching results in a treelike epithelial structure surrounded by mesenchyme. Further growth and elaboration of this structure over time eventually gives rise to the adult pancreas with exocrine tissues located at the tip of the duct system and interspersed islets of Langerhans that harbor $\beta$ cells (Fig. 1).

\section{$\beta$-cell Lineage}

Cell-type specification in the pancreas is thought to proceed in a stepwise fashion similar to the hematopoietic system where multipotent progenitors give rise to celltype-specific precursor cells that subsequently produce mature cell types (Murtaugh 2007). Genetic lineage-tracing studies provide evidence for the existence of such a pancreatic multipotent progenitor (Zhou et al. 2007). These cells appear to reside in the early pancreatic buds and later, when the branching begins, at the tip of the branches. They give rise to all pancreatic cell types, including exocrine, endocrine, and duct cells.

A unique aspect of the early pancreatic progenitor cells is that they do not appear to have significant compensatory growth in response to a reduction in number (Stanger et al. 2007). Unlike organs such as liver, where reduction of progenitor numbers results in growth compensation and a 


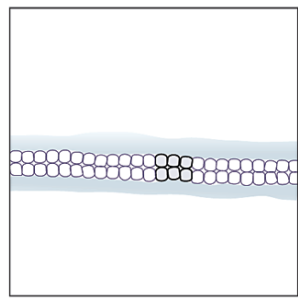

Pancreatic domain

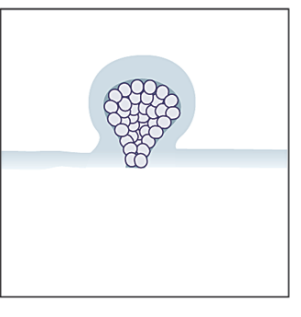

Pancreatic bud

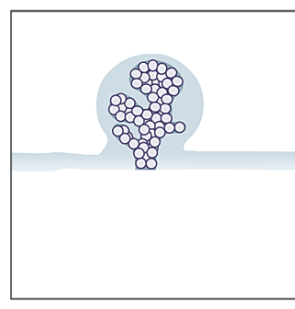

Branching

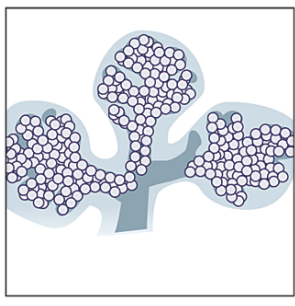

Growth

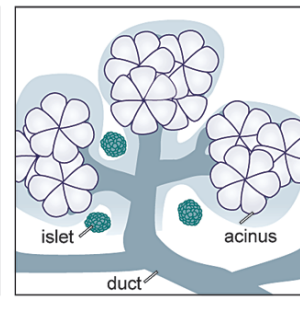

Adult

Figure 1. Pancreatic development. Schematic drawings of different stages of pancreatic development. At all stages, the epithelium is surrounded by a layer of mesenchyme. Pancreatic bud formation and branching are shown for dorsal pancreas only.

final organ of normal size, reduction of pancreatic progenitors results in a proportionately smaller pancreas.

Details about lineage-restricted precursor cells produced from multipotent pancreatic progenitors remain unresolved. What is clear, however, is that a population of endocrine precursors, recognized by the marker gene Ngn3, appears at midgestation among developing epithelial cells. Genetic lineage-tracing and knockout studies demonstrated convincingly that $\mathrm{Ngn}^{+}$cells give rise to all pancreatic endocrine cells including $\beta$ cells and that they are the only source of $\beta$ cells during embryogenesis (Gradwohl et al. 2000; Schwitzgebel et al. 2000; Gu et al. 2002). Newly generated endocrine cells migrate out of epithelium into the surrounding mesenchyme and coalesce into clusters. These are precursors of the islets of Langerhans.

\section{Genes in Development}

Many genes associated with embryonic development of the pancreas and $\beta$ cells have been identified (Wilson et al. 2003; Jensen 2004). These include transcription factors such as Pdx1, Ptfla, and Ngn3, and secreted molecules of the Hedgehog $(\mathrm{HH})$, fibroblast growth factor (FGF), retinoic acid (RA), Notch, and Wnt families. Their importance is largely demonstrated through gene knockout studies, where phenotypes involving pancreas and/or $\beta$ cells were observed. These studies mostly establish the necessity of the genes in pancreas and $\beta$-cell development, but few have addressed the issue of whether any of them are sufficient to instruct the generation of particular pancreatic cell types. For example, it is not clear what signals would be sufficient to direct early endoderm to adopt the pancre- atic cell fate or to promote $\mathrm{Ngn}^{+}$precursor cells to become $\beta$ cells. Nevertheless, a number of factors can strongly bias pancreatic fate choices. For example, $\mathrm{SHH}$ inhibits pancreatic domain formation from early endoderm (Hebrok et al. 2000); expression of activated Pdx1 under certain conditions can convert part of the liver domain to pancreas (Horb et al. 2003); ngn3 expression in early pancreatic progenitors appears to be sufficient to promote endocrine cell fates (Johansson et al. 2007); and Notch signaling functions to maintain progenitor cells in undifferentiated states (Apelqvist et al. 1999; Jensen et al. 2000; Murtaugh et al. 2003). These factors have subsequently been used in various approaches to generate new $\beta$ cells.

\section{RECAPITULATING DEVELOPMENT: DIRECTED DIFFERENTIATION OF B CELLS FROM EMBRYONIC STEM CELLS}

\section{Recent Progress}

Many studies have been carried out in recent years to generate $\beta$ cells by differentiation from ES cells (Spence and Wells 2007). This is based on the premise that pluripotent ES cells have the ability to generate any cell type in the body and that key steps of $\beta$-cell development may be recapitulated in culture. Indeed, as we discussed above, the key steps for $\beta$-cell development are known: from definitive endoderm to pancreatic progenitors, endocrine precursors, and finally mature $\beta$ cells (Fig. 2). Some factors that promote the progression from one step to another are also known, and cells that reach each developmental stage can be recognized by their expression of unique gene products (Fig. 2).

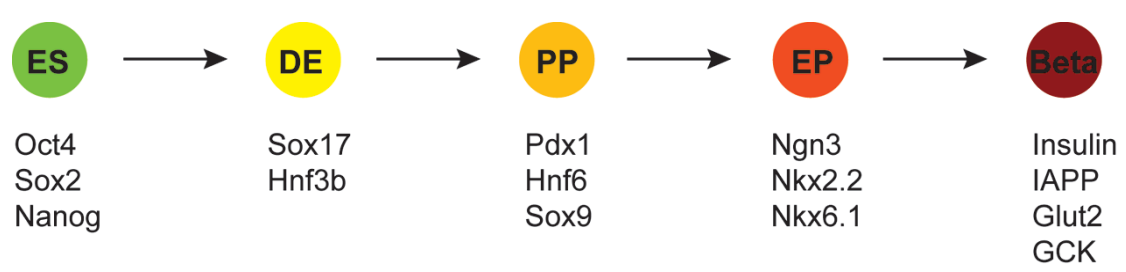

Figure 2. Directed differentiation from embryonic stem cells. There are four major steps that lead from ES cells to $\beta$ cells. These are definitive endoderm (DE), pancreatic progenitor cells (PP), endocrine progenitors (EP), and mature $\beta$ cells (Beta). Some markers that define each cell type are listed. 
Using a protocol of stepwise differentiation based on conclusions from other studies of normal pancreatic development, significant advances have been made to produce $\beta$ cells from human ES cells (D'Amour et al. 2005, 2006; Kroon et al. 2008). This protocol uses Activin/Nodal to convert a monolayer culture of ES cells into cells that resemble definitive endoderm. Suppression of SHH signaling and addition of other permissive factors allow some of the cells to further develop into pancreatic and endocrine progenitor-like cells in culture. These cells are subsequently transplanted into mice where they appear to mature into various endocrine cell types including $\beta$ cells, organize into islet-like structures, and gain the ability to ameliorate hyperglycemia.

\section{Issues That Remain}

The encouraging results from human ES differentiation, while validating the ES cell approach, also point to several remaining hurdles. So far, little is known about the factors that promote pancreatic endocrine precursors to become $\beta$ cells and even less is known about the factors that induce maturation of $\beta$ cells. These two steps are now accomplished by transplanting progenitor cells into host animals where the signals and mechanisms remain opaque. The size, composition, and organization of the resulting cellular mass from progenitor cell differentiation in vivo are unpredictable. Therefore, although directly supplying pancreatic progenitor cells to patients may be clinically possible, it is more desirable to derive mature $\beta$ cells for transplantation and that requires finding a way to produce mature $\beta$ cells in culture in a controlled manner.

Part of the difficulty in deriving fully mature $\beta$ cells in culture may reflect an inadequate in vitro environment. In vivo $\beta$ cells develop in a three-dimensional structure with extensive interactions with a diverse array of cell types that includes mesenchymal and endothelial cells (Rutter et al. 1978; Nikolova et al. 2006). The current ES derivation protocol, however, uses a two-dimensional culture system that is largely devoid of other cell types. Reintroducing mesenchymal and endothelial cells or the signals they produce into the culture system may promote further $\beta$-cell differentiation.

It has been shown recently that different human ES cell lines exhibit marked differences in differentiation potential into different cell types, with variations as large as 100-fold (Adewumi et al. 2007; Osafune et al. 2008). It is therefore necessary to optimize the human ES lines used for each derivation protocol by screening through multiple human ES cell lines.

Each adult human has about 1 billion $\beta$ cells. Producing such large numbers of cells requires a highly efficient process. Current methods of ES differentiation rely on protein factors that are expensive and varying in quality. To improve consistency and efficiency of $\beta$-cell derivation, it will likely be advantageous to identify small molecules that can replace the function of these protein factors.

Finally, it has long been known that islet structure is important for $\beta$-cell function and that intra-islet $\beta$-cell inter- actions serve to suppress basal insulin secretion and enhance glucose-stimulated insulin release (Konstantinova et al. 2007). Any effort to produce fully functional $\beta$ cells would likely benefit from proper reconstruction of the three-dimensional islet structure with the associated endocrine cell types in vitro.

\section{Patient-specific $\beta$ cells: Combining iPS Technology with Directed Differentiation}

In the past, human ES cell lines were derived from embryos. Recent advances in stem cell reprogramming raised the possibility of generating patient-specific induced pluripotent stem (iPS) cells from skin cells of individual patients (Takahashi and Yamanaka 2006; Takahashi et al. 2007; Yu et al. 2007), which can be redifferentiated to produce patient-specific $\beta$ cells. Although there are some remaining concerns with stem cell reprogramming, notably the use of viruses that may cause cancer, these problems are expected to be overcome in the near future. The iPS approach also carries some risks. Extensive cellular proliferation in culture during skin-tostem-cell reprogramming and the subsequent differentiation of iPS cells may encourage accumulation of genetic mutations that allow the cells to survive and proliferate better in culture. This may increase the likelihood that differentiated cell types are predisposed for malignant transformation. In addition, contamination of differentiated cells by undifferentiated stem cells may also lead to teratoma formation. Properly addressing these risks would be necessary before clinical applications.

\section{STRATEGIES BASED ON $\beta$-CELL REPLICATION}

The formation of $\beta$ cells during embryogenesis is followed by a period of rapid proliferation during early postnatal life when $\beta$-cell number increases to meet physiological demand. During adult life, $\beta$-cell mass is maintained at a constant level with very slow cellular turnover (Teta et al. 2005). Recent genetic experiments demonstrate that adult $\beta$ cells derive from self-duplication of existing $\beta$ cells (Dor et al. 2004). Clonal analysis and lineage-tracing studies further suggest that all $\beta$ cells have equal potential for replication (Brennand et al. 2007; Teta et al. 2007). Stimulating proliferation of existing adult $\beta$ cells is a very attractive approach for supplying new $\beta$ cells as the $\beta$ cells are immunologically fully matched with individual patients.

\section{Signals That Influence $\beta$-cell Replication}

Many intracellular and extracellular factors are known to influence proliferation and apoptosis of $\beta$ cells (Heit et al. 2006). For example, direct manipulation of cell cycle regulators, including cyclins, cyclin-dependent kinases $(\mathrm{CDK})$, and $\mathrm{CDK}$ inhibitors (CDI), changes $\beta$-cell proliferation, with some resulting in $\beta$-cell hyperplasia (Heit et al. 2006). However, direct manipulations of cell cycle regulators often lead to cancer (Sherr and Roberts 2004). 
In addition, cell cycle regulators are normally expressed in multiple cell types, and changes in their levels may cause growth and apoptosis changes of an array of cell types. These concerns have led to searches for extracellular signals that function under physiological conditions to promote $\beta$-cell replication.

Despite the typical slow growth rate of adult $\beta$ cells, $\beta$ cell mass can expand dramatically during pregnancy (Van Assche et al. 1978; Scaglia et al. 1995; Kahn et al. 2006). There is evidence that prolactin and placental lactogen, two maternal hormones, can directly regulate $\beta$-cell proliferation during pregnancy through the intracellular factor Menin (Parsons et al. 1992; Brelje et al. 1993; Sorenson and Brelje 1997; Karnik et al. 2007). However, the actions of these hormones are complicated and the prospect of using them as a therapy to increase $\beta$-cell number is unclear.

$\beta$-cell number also increases in obesity or genetic insulin resistance in both human and animals (Kahn et al. 2006). Strikingly, in some genetic models of peripheral insulin resistance, such as liver-specific deletion of insulin receptor (LIRKO), an almost tenfold islet hyperplasia is observed (Michael et al. 2000). Under insulin resistance conditions, blood glucose levels are elevated and insulin secretion is enhanced. Interestingly, both glucose and insulin have been suggested to be $\beta$-cell mitogens (Chick 1973; Kulkarni 2005). Indeed, infusion of either glucose or insulin into animal models results in increased $\beta$-cell proliferation and mass (Bonner-Weir et al. 1989; Paris et al. 2003). On the other hand, the actions of glucose and insulin are tightly linked. Glucose stimulates insulin release from $\beta$ cells, which can subsequently trigger autocrine insulin signaling (Kulkarni 2002). It has proved to be difficult to separate the effect of glucose from insulin, and it remains unclear whether glucose/insulin are primarily responsible for increased $\beta$-cell proliferation under insulin-resistant conditions or whether other factors primarily drive this process.

\section{Issues That Remain}

Factors that are currently known for $\beta$-cell proliferation, such as prolactin, glucose, and insulin, are not suitable for direct application in therapies. Nevertheless, studies of them and the associated signaling pathways may eventually yield better targets for therapeutic interventions. It is also possible to directly screen for factors and chemical compounds that stimulate $\beta$-cell replication. One way to achieve this is to develop an in vitro culture system for islets or isolated $\beta$ cells that allows rapid screening of large numbers of factors and compounds.

To achieve patient-specific therapies, it is important that the growth-stimulating factors can be administered directly in vivo and that their actions are specific to $\beta$ cells or whole islets but not to other cell types. This specificity may be accomplished by exploiting mechanisms such as differential expression of certain glucose transporters in $\beta$ cells that selectively import specific molecules into $\beta$ cells.

The major risk associated with this strategy of increasing $\beta$-cell mass is the danger of cancer, especially if the agents used are not highly specific and induce changes in proliferation and apoptosis of pancreatic duct or exocrine cells. This may lead to pancreatic cancers, a particularly deadly class of tumors.

\section{New Injury Model to Study $\beta$-cell Replication}

In some organ systems such as the liver, studies of injury models have revealed important factors and pathways that mediate compensatory cellular proliferation (Taub 2004). Adult pancreas, however, appears to have very limited compensatory growth in various injury models (Tanigawa et al. 1997). Recently, a new study with inducible genetic ablation of $\beta$ cells provided evidence for robust compensatory $\beta$-cell growth (Nir et al. 2007). The development of this model system provides a new avenue of investigating $\beta$-cell proliferation.

\section{Dedifferentiation from Adult Islet Cells}

It was suggested recently that $\beta$ cells in cultured islets may dedifferentiate into proliferating progenitor-like cells (Gershengorn et al. 2004). Some of these fibroblast-like cells can be induced to redifferentiate and reexpress insulin. Whether these insulin-expressing cells represent bona fide $\beta$ cells, however, has yet to be established. In addition, a recent study showed that the proliferating fibroblast-like cells do not derive from existing $\beta$ cells (Morton et al. 2007). Their origin remains mysterious. Even if functional $\beta$ cells can be produced with islet dedifferentiation, it would not be suitable for patient-specific therapies because it would be difficult to collect islets from individuals.

\section{STRATEGIES BASED ON PUTATIVE ADULT PROGENITOR CELLS OR FACULTATIVE STEM CELLS}

Basis on certain histological observations, it has long been hypothesized that adult endocrine progenitor cells or facultative stem cells may exist in adult pancreas (Bonner-Weir and Weir 2005). A recent study showed that a small number of $\mathrm{Ngn}^{+}$cells arise in adult mouse pancreas after partial duct ligation (PDL) and some of them are capable of further development into endocrine cells that include $\beta$ cells (Xu et al. 2008). Nevertheless, it is not clear whether this event represents the mobilization of existing adult endocrine progenitor cells that already express low levels of Ngn3, activation of dormant stemlike cells, or conversion of other cells into endocrine cells under the PDL conditions. Moreover, the factors involved in this process remain unknown and the number of $\mathrm{Ngn}^{+}$ progenitor cells produced is very small. In addition, the adult pancreas may be a nonpermissive environment for differentiation of progenitor cells. These are formidable challenges and major progress is clearly needed to make this approach a viable strategy for producing new $\beta$ cells.

\section{REPROGRAMMING NON- $\beta$ CELLS TO $\beta$ CELLS}

In rare cases, cells of one lineage can be converted into cells of another lineage (Slack 2007). For example, embryonic dermal fibroblasts and pigmented epithelial cells can 
Table 1. Comparison of current approaches to produce new $\beta$ cells

\begin{tabular}{|c|c|c|c|c|}
\hline & ES differentiation & $\beta$-cell replication & Adult progenitor & Reprogramming \\
\hline Instructive factors & some known & some known & unknown & known \\
\hline Patient specificity & possible with iPS & $\begin{array}{l}\text { possible with direct } \\
\text { in vivo replication }\end{array}$ & $\begin{array}{l}\text { possible with direct } \\
\text { in vivo induction }\end{array}$ & $\begin{array}{l}\text { possible with in vivo or } \\
\text { in vitro conversion }\end{array}$ \\
\hline Starting material & abundant skin cells & existing $\beta$ cells & unknown & $\begin{array}{l}\text { abundant exocrine and } \\
\text { liver cells }\end{array}$ \\
\hline$\beta$-like cells produced & yes, large number & yes, large number & yes, very small number & yes, large number \\
\hline
\end{tabular}

be converted to contracting myocytes, whereas mature $\beta$ cells can be reprogrammed into macrophages (Choi et al. 1990; Xie et al. 2004). These examples have led to research into potential ways to reprogram non- $\beta$ cells, such as pancreatic exocrine cell, duct cells, and liver cells, into $\beta$ cells (Ferber et al. 2000; Heremans et al. 2002; Gasa et al. 2004; Kaneto et al. 2005). Most of these efforts, however, have resulted in gene expression changes but not cell-type conversions. Interestingly, mature exocrine cells of the pancreas can turn on endocrine cell programs in culture (Minami et al. 2005). Dissociation itself is apparently sufficient to initiate the endocrine programs, whereas the addition of growth factors improves cell survival (Baeyens et al. 2005; Minami and Seino 2008). The molecular mechanism of this phenomenon, however, remains largely unknown.

Recent experiments in our laboratory showed that reprogramming of non- $\beta$ cells to $\beta$ cells can be achieved in an instructive manner. We demonstrated that a simple combination of three transcription factors is sufficient to convert fully differentiated pancreatic exocrine cells in adult mice into cells that closely resemble $\beta$ cells in morphology, ultrastructure, molecular signatures, and function.

A key challenge of the reprogramming approach is that induced $\beta$ cells persist as individual cells or small clusters and do not organize into islets. In addition, viruses are currently used to express the reprogramming factors. They would need to be replaced by safer reagents such as chemical compounds.

There are several potential ways to achieve patient specificity with the reprogramming approach. For example, given the difficulty of biopsying human pancreas, reagents can be developed to convert pancreatic exocrine cells directly in vivo. Alternatively, adult liver cells can be relatively easily harvested from individuals and used for reprogramming in vitro to produce $\beta$ cells for subsequent transplants.

\section{CONCLUSIONS}

Different strategies have been proposed in recent years to produce new $\beta$ cells. Each of these strategies has merits and drawbacks (Table 1), and so far, the most promising strategy appears to be the one based on differentiation of human ES cells.

Before transferring the ongoing research into clinics, several common issues face all of these approaches. Diabetes, after all, can be treated effectively with insulin for long term. Any cell therapies based on new $\beta$ cells will be scrutinized and stringent criteria will be demanded. First, new $\beta$ cells are expected to resemble endogenous $\beta$ cells in function and that requires islet structure formation. Second, new $\beta$ cells are expected to be patient-specific. Third, they must be safe to use for the long term. Various risk factors, particularly cancers, should be properly addressed before clinical applications.

Current approaches for producing $\beta$ cells still remain at early research and development stages; it is difficult to foresee which approach may eventually yield $\beta$ cells that are therapeutically useful. Given the severity and increasing prevalence of diabetes, each of these strategies, and potential new innovative approaches, should be pursued in earnest. From a broader perspective, a major goal of regenerative medicine is to generate new cells to replace those lost due to disease or damage. Successes in regenerating new $\beta$ cells should inform other cell-based therapeutic strategies.

\section{ACKNOWLEDGMENTS}

We thank many of the past and present members of the Melton laboratory for stimulating discussions on pancreas and $\beta$ cells. We apologize to colleagues whose work we could not cite due to space limitations. We thank Drs. Justin Annes and Jay Rajagopal for critical readings of this manuscript. Q.Z. was supported by a Damon-Runyon Cancer Research Foundation postdoctoral fellowship and a Pathway to Independence (PI) Award from the National Institutes of Health (NIH). D.A.M. is a Howard Hughes Medical Institute (HHMI) investigator, and work in the laboratory was supported in part by the Harvard Stem Cell Institute, HHMI, JDRF, and the NIH.

\section{REFERENCES}

Adewumi, O., Aflatoonian, B., Ahrlund-Richter, L., Amit, M., Andrews, P.W., Beighton, G., Bello, P.A., Benvenisty, N., Berry, L.S., Bevan, S., et al. 2007. Characterization of human embryonic stem cell lines by the International Stem Cell Initiative. Nat. Biotechnol. 25: 803-816.

Apelqvist, A., Li, H., Sommer, L., Beatus, P., Anderson, D.J., Honjo, T., Hrabe de Angelis, M., Lendahl, U., and Edlund, H. 1999. Notch signalling controls pancreatic cell differentiation. Nature 400: 877-881.

Baeyens, L., De Breuck, S., Lardon, J., Mfopou, J.K., Rooman, I., and Bouwens, L. 2005. In vitro generation of insulin-producing $\beta$ cells from adult exocrine pancreatic cells. Diabetologia 48: 49-57.

Bell, G.I. and Polonsky, K.S. 2001. Diabetes mellitus and genetically programmed defects in $\beta$-cell function. Nature 414: 788-791.

Bonner-Weir, S. and Weir, G.C. 2005. New sources of pancreatic $\beta$ cells. Nat. Biotechnol. 23: 857-861.

Bonner-Weir, S., Deery, D., Leahy, J.L., and Weir, G.C. 1989. 
Compensatory growth of pancreatic $\beta$ cells in adult rats after short-term glucose infusion. Diabetes 38: 49-53.

Brelje, T.C., Scharp, D.W., Lacy, P.E., Ogren, L., Talamantes, F., Robertson, M., Friesen, H.G., and Sorenson, R.L. 1993. Effect of homologous placental lactogens, prolactins, and growth hormones on islet $\beta$-cell division and insulin secretion in rat, mouse, and human islets: Implication for placental lactogen regulation of islet function during pregnancy. Endocrinology 132: 879-887.

Brennand, K., Huangfu, D., and Melton, D. 2007. All $\beta$ cells contribute equally to islet growth and maintenance. PLoS Biol. 5: e163.

Chick, W.L. 1973. $\beta$ Cell replication in rat pancreatic monolayer cultures. Effects of glucose, tolbutamide, glucocorticoid, growth hormone and glucagon. Diabetes 22: 687-693.

Choi, J., Costa, M.L., Mermelstein, C.S., Chagas, C., Holtzer, S., and Holtzer, H. 1990. MyoD converts primary dermal fibroblasts, chondroblasts, smooth muscle, and retinal pigmented epithelial cells into striated mononucleated myoblasts and multinucleated myotubes. Proc. Natl. Acad. Sci. 87: 7988-7992.

D’Amour, K.A., Agulnick, A.D., Eliazer, S., Kelly, O.G., Kroon, E., and Baetge, E.E. 2005. Efficient differentiation of human embryonic stem cells to definitive endoderm. Nat. Biotechnol. 23: 1534-1541.

D’Amour, K.A., Bang, A.G., Eliazer, S., Kelly, O.G., Agulnick, A.D., Smart, N.G., Moorman, M.A., Kroon, E., Carpenter, M.K., and Baetge, E.E. 2006. Production of pancreatic hormone-expressing endocrine cells from human embryonic stem cells. Nat. Biotechnol. 24: 1392-1401.

Daneman, D. 2006. Type 1 diabetes. Lancet 367: 847-858.

Dor, Y., Brown, J., Martinez, O.I., and Melton, D.A. 2004 . Adult pancreatic $\beta$ cells are formed by self-duplication rather than stem-cell differentiation. Nature 429: 41-46.

Edlund, H. 2001. Developmental biology of the pancreas. Diabetes (suppl. 1) 50: S5-S9.

Ferber, S., Halkin, A., Cohen, H., Ber, I., Einav, Y., Goldberg, I., Barshack, I., Seijffers, R., Kopolovic, J., Kaiser, N., et al. 2000. Pancreatic and duodenal homeobox gene 1 induces expression of insulin genes in liver and ameliorates streptozotocin-induced hyperglycemia. Nat. Med. 6: 568-572.

Gasa, R., Mrejen, C., Leachman, N., Otten, M., Barnes, M., Wang, J., Chakrabarti, S., Mirmira, R., and German, M. 2004. Proendocrine genes coordinate the pancreatic islet differentiation program in vitro. Proc. Natl. Acad. Sci. 101: 13245-13250.

Gershengorn, M.C., Hardikar, A.A., Wei, C., Geras-Raaka, E., Marcus-Samuels, B., and Raaka, B.M. 2004. Epithelial-tomesenchymal transition generates proliferative human islet precursor cells. Science 306: 2261-2264.

Gradwohl, G., Dierich, A., LeMeur, M., and Guillemot, F. 2000. neurogenin 3 is required for the development of the four endocrine cell lineages of the pancreas. Proc. Natl. Acad. Sci. 97: 1607-1611.

Gu, G., Dubauskaite, J., and Melton, D.A. 2002. Direct evidence for the pancreatic lineage: $\mathrm{NGN}^{+}$cells are islet progenitors and are distinct from duct progenitors. Development 129: $2447-2457$.

Hebrok, M., Kim, S.K., St-Jacques, B., McMahon, A.P., and Melton, D.A. 2000. Regulation of pancreas development by hedgehog signaling. Development 127: 4905-4913.

Heit, J.J., Karnik, S.K., and Kim, S.K. 2006. Intrinsic regulators of pancreatic $\beta$-cell proliferation. Annu. Rev. Cell Dev. Biol. 22: $311-338$

Heremans, Y., Van De Casteele, M., in’t Veld, P., Gradwohl, G., Serup, P., Madsen, O., Pipeleers, D., and Heimberg, H. 2002. Recapitulation of embryonic neuroendocrine differentiation in adult human pancreatic duct cells expressing neurogenin 3 . J. Cell Biol. 159: 303-312.

Horb, M.E., Shen, C.N., Tosh, D., and Slack, J.M. 2003. Experimental conversion of liver to pancreas. Curr. Biol. 13: 105-115.

Jensen, J. 2004. Gene regulatory factors in pancreatic development. Dev. Dyn. 229: 176-200.

Jensen, J., Pedersen, E.E., Galante, P., Hald, J., Heller, R.S., Ishibashi, M., Kageyama, R., Guillemot, F., Serup, P., and
Madsen, O.D. 2000. Control of endodermal endocrine development by Hes-1. Nat. Genet. 24: 36-44.

Johansson, K.A., Dursun, U., Jordan, N., Gu, G., Beermann, F., Gradwohl, G., and Grapin-Botton, A. 2007. Temporal control of neurogenin 3 activity in pancreas progenitors reveals competence windows for the generation of different endocrine cell types. Dev. Cell 12: 457-465.

Kahn, S.E. 2004. Engineering a new $\beta$-cell: A critical venture requiring special attention to constantly changing physiological needs. Semin. Cell Dev. Biol. 15: 359-370.

Kahn, S.E., Hull, R.L., and Utzschneider, K.M. 2006. Mechanisms linking obesity to insulin resistance and type 2 diabetes. Nature 444: 840-846.

Kaneto, H., Nakatani, Y., Miyatsuka, T., Matsuoka, T.A., Matsuhisa, M., Hori, M., and Yamasaki, Y. 2005. PDX1/VP16 fusion protein, together with NeuroD or Ngn3, markedly induces insulin gene transcription and ameliorates glucose tolerance. Diabetes 54: 1009-1022.

Karnik, S.K., Chen, H., McLean, G.W., Heit, J.J., Gu, X., Zhang, A.Y., Fontaine, M., Yen, M.H., and Kim, S. K. 2007. Menin controls growth of pancreatic $\beta$ cells in pregnant mice and promotes gestational diabetes mellitus. Science 318: 806-809.

Konstantinova, I., Nikolova, G., Ohara-Imaizumi, M., Meda, P., Kucera, T., Zarbalis, K., Wurst, W., Nagamatsu, S., and Lammert, E. 2007. EphA-Ephrin-A-mediated $\beta$ cell communication regulates insulin secretion from pancreatic islets. Cell 129: 359-370.

Kroon, E., Martinson, L.A., Kadoya, K., Bang, A.G., Kelly, O.G., Eliazer, S., Young, H., Richardson, M., Smart, N.G., Cunningham, J., et al. 2008. Pancreatic endoderm derived from human embryonic stem cells generates glucose-responsive insulin-secreting cells in vivo. Nat. Biotechnol. 26: $443-452$.

Kulkarni, R.N. 2002. Receptors for insulin and insulin-like growth factor-1 and insulin receptor substrate-1 mediate pathways that regulate islet function. Biochem. Soc. Trans. 30: $317-322$

Kulkarni, R.N. 2005. New insights into the roles of insulin/IGFI in the development and maintenance of $\beta$-cell mass. Rev. Endocr. Metab. Disord. 6: 199-210.

Lakey, J.R., Mirbolooki, M., and Shapiro, A.M. 2006. Current status of clinical islet cell transplantation. Methods Mol. Biol. 333: 47-104.

Lammert, E., Cleaver, O., and Melton, D. 2001. Induction of pancreatic differentiation by signals from blood vessels. Science 294: 564-567.

Michael, M.D., Kulkarni, R.N., Postic, C., Previs, S.F., Shulman, G.I., Magnuson, M.A., and Kahn, C.R. 2000. Loss of insulin signaling in hepatocytes leads to severe insulin resistance and progressive hepatic dysfunction. Mol. Cell 6: 87-97.

Minami, K. and Seino, S. 2008. Pancreatic acinar-to- $\beta$ cell transdifferentiation in vitro. Front. Biosci. 13: 5824-5837.

Minami, K., Okuno, M., Miyawaki, K., Okumachi, A., Ishizaki, K., Oyama, K., Kawaguchi, M., Ishizuka, N., Iwanaga, T., and Seino, S. 2005. Lineage tracing and characterization of insulin-secreting cells generated from adult pancreatic acinar cells. Proc. Natl. Acad. Sci. 102: 15116-15121.

Morton, R.A., Geras-Raaka, E., Wilson, L.M., Raaka, B.M., and Gershengorn, M.C. 2007. Endocrine precursor cells from mouse islets are not generated by epithelial-to-mesenchymal transition of mature $\beta$ cells. Mol. Cell. Endocrinol. 270: 87-93.

Murtaugh, L.C. 2007. Pancreas and $\beta$-cell development: From the actual to the possible. Development 134: 427-438.

Murtaugh, L.C., Stanger, B.Z., Kwan, K.M., and Melton, D.A. 2003. Notch signaling controls multiple steps of pancreatic differentiation. Proc. Natl. Acad. Sci. 100: 14920-14925.

Nikolova, G., Jabs, N., Konstantinova, I., Domogatskaya, A., Tryggvason, K., Sorokin, L., Fassler, R., Gu, G., Gerber, H.P., Ferrara, N., et al. 2006. The vascular basement membrane: A niche for insulin gene expression and $\beta$ cell proliferation. Dev. Cell 10: 397-405. 
Nir, T., Melton, D.A., and Dor, Y. 2007. Recovery from diabetes in mice by $\beta$ cell regeneration. J. Clin. Invest. 117: 2553-2561.

Osafune, K., Caron, L., Borowiak, M., Martinez, R.J., FitzGerald, C.S., Sato, Y., Cowan, C.A., Chien, K.R., and Melton, D.A. 2008. Marked differences in differentiation propensity among human embryonic stem cell lines. Nat. Biotechnol. 26: 313-315.

Paris, M., Bernard-Kargar, C., Berthault, M.F., Bouwens, L., and Ktorza, A. 2003. Specific and combined effects of insulin and glucose on functional pancreatic $\beta$-cell mass in vivo in adult rats. Endocrinology 144: 2717-2127.

Parsons, J.A., Brelje, T.C., and Sorenson, R.L. 1992. Adaptation of islets of Langerhans to pregnancy: Increased islet cell proliferation and insulin secretion correlates with the onset of placental lactogen secretion. Endocrinology 130: 1459-1466.

Rutter, W.J., Pictet, R.L., Harding, J.D., Chirgwin, J.M., MacDonald, R.J., and Przybyla, A.E. 1978. An analysis of pancreatic development: Role of mesenchymal factor and other extracellular factors. Symp. Soc. Dev. Biol. 1978: 205-227.

Scaglia, L., Smith, F.E., and Bonner-Weir, S. 1995. Apoptosis contributes to the involution of $\beta$ cell mass in the post partum rat pancreas. Endocrinology 136: 5461-5468.

Schwitzgebel, V.M., Scheel, D.W., Conners, J.R., Kalamaras, J., Lee, J.E., Anderson, D.J., Sussel, L., Johnson, J.D., and German, M.S. 2000. Expression of neurogenin3 reveals an islet cell precursor population in the pancreas. Development 127: 3533-3542.

Sherr, C.J. and Roberts, J.M. 2004. Living with or without cyclins and cyclin-dependent kinases. Genes Dev. 18: 2699-2711.

Slack, J.M. 1995. Developmental biology of the pancreas. Development 121: 1569-1580.

Slack, J.M. 2007. Metaplasia and transdifferentiation: From pure biology to the clinic. Nat. Rev. Mol. Cell Biol. 8: 369-378.

Sorenson, R.L. and Brelje, T.C. 1997. Adaptation of islets of Langerhans to pregnancy: $\beta$-cell growth, enhanced insulin secretion and the role of lactogenic hormones. Horm. Metab. Res. 29: 301-307.

Spence, J.R. and Wells, J.M. 2007. Translational embryology: Using embryonic principles to generate pancreatic endocrine cells from embryonic stem cells. Dev. Dyn. 236: 3218-3227.

Stanger, B.Z., Tanaka, A.J., and Melton, D.A. 2007. Organ size is limited by the number of embryonic progenitor cells in the pancreas but not the liver. Nature 445: 886-891.

Takahashi, K. and Yamanaka, S. 2006. Induction of pluripotent stem cells from mouse embryonic and adult fibroblast cultures by defined factors. Cell 126: 663-676.

Takahashi, K., Tanabe, K., Ohnuki, M., Narita, M., Ichisaka, T., Tomoda, K., and Yamanaka, S. 2007. Induction of pluripotent stem cells from adult human fibroblasts by defined factors. Cell 131: 861-872.

Tanigawa, K., Nakamura, S., Kawaguchi, M., Xu, G., Kin, S., and Tamura, K. 1997. Effect of aging on $\beta$-cell function and replication in rat pancreas after $90 \%$ pancreatectomy. Pancreas 15: 53-59.

Taub, R. 2004. Liver regeneration: From myth to mechanism. Nat. Rev. Mol. Cell Biol. 5: 836-847.

Teta, M., Long, S.Y., Wartschow, L.M., Rankin, M.M., and Kushner, J.A. 2005. Very slow turnover of $\beta$ cells in aged adult mice. Diabetes 54: 2557-2567.

Teta, M., Rankin, M.M., Long, S.Y., Stein, G.M., and Kushner, J.A. 2007. Growth and regeneration of adult $\beta$ cells does not involve specialized progenitors. Dev. Cell. 12: 817-826.

Van Assche, F.A., Aerts, L., and De Prins, F. 1978. A morphological study of the endocrine pancreas in human pregnancy. Br. J. Obstet. Gynaecol. 85: 818-820.

Wilson, M.E., Scheel, D., and German, M.S. 2003. Gene expression cascades in pancreatic development. Mech. Dev. 120: 65-80.

Xie, H., Ye, M., Feng, R., and Graf, T. 2004. Stepwise reprogramming of $\beta$ cells into macrophages. Cell 117: 663-676.

Xu, X., D'Hoker, J., Stange, G., Bonne, S., De Leu, N., Xiao, X., Van de Casteele, M., Mellitzer, G., Ling, Z., Pipeleers, D., et al. 2008. $\beta$ Cells can be generated from endogenous progenitors in injured adult mouse pancreas. Cell 132: 197-207.

Yu, J., Vodyanik, M.A., Smuga-Otto, K., Antosiewicz-Bourget, J., Frane, J.L., Tian, S., Nie, J., Jonsdottir, G.A., Ruotti, V., Stewart, R., et al. 2007. Induced pluripotent stem cell lines derived from human somatic cells. Science 318: 1917-1920.

Zaret, K.S. 2008. Genetic programming of liver and pancreas progenitors: Lessons for stem-cell differentiation. Nat. Rev. Genet. 9: 329-340.

Zhou, Q., Law, A.C., Rajagopal, J., Anderson, W.J., Gray, P.A., and Melton, D.A. 2007. A multipotent progenitor domain guides pancreatic organogenesis. Dev. Cell 13: 103-114. 


\section{$\overbrace{\text { CSH' }}^{\infty}$ Cold Spring Harbor Symposia SYMPOSIA}

\section{Pathways to New $\beta$ Cells}

Q. Zhou and D.A. Melton

Cold Spring Harb Symp Quant Biol 2008 73: 175-181 originally published online November 6, 2008 Access the most recent version at doi:10.1101/sqb.2008.72.002

References This article cites 70 articles, 19 of which can be accessed free at: http://symposium.cshlp.org/content/73/175.full.html\#ref-list-1

License

Email Alerting Receive free email alerts when new articles cite this article - sign up in the Service box at the top right corner of the article or click here. 